\title{
Substantiation of the advanced training program "Social work with military personnel and military-social work in the context of sustainable development goals"
}

\author{
Iryna Trubavina ${ }^{1, *}$, Mykhailo Medvid ${ }^{1}$, Andrew M. Cwer ${ }^{2}$, Ludmyla Petryshyn ${ }^{3}$, and Halyna Meshko ${ }^{3}$ \\ ${ }^{1}$ National Academy of the National Guard of Ukraine, 3 Zakhysnykiv Ukrainy Sq., Kharkiv, 61003, Ukraine \\ ${ }^{2}$ The Higher School of Tourism and Foreign Languages in Warsaw, Al. Prymasa Tysiąclecia 38 A, 01-242 Warsaw, Poland \\ ${ }^{3}$ Ternopil Volodymyr Hnatiuk National Pedagogical University, 2 Maksyma Kryvonosa Str., Ternopil, 46000, Ukraine.
}

\begin{abstract}
The article is devoted to the implementation of sustainable development goals in the training of social employees and military personnel engaged in military and social work. The purpose of the research is to develop a training program "Social work with military staff and military-social work". There were used such research methods as comparative analysis, theoretical analysis, generalization, survey, modeling, synthesis. The result of the article is the developed program that consist of three modules. Among them there are such modules as "Digital tools for teaching social work", "Theoretical foundations of social work with servicemen and their families", and "Practice of social work with servicemen and their families in the community". The program features are following: a training form and a set of approaches to its content. There are the program prerequisites for the study result implementation such as the mastering by teachers of the tools of media education, the distance technologies and their methods of use, and interaction of community specialists with military component in training. The prospects for further research are the development of specialization disciplines in the higher education institutions on the research issue. The scientific novelty consists of a set of scientific approaches in the program content developing, clarifying the essence of the "military and social work" concept and others.
\end{abstract}

\section{Introduction}

We associate the relevance of our research with the fact that:

1. Sustainable development means improving conditions for maintaining health, peace and harmony in countries and communities, ensuring gender equality, overcoming poverty and hunger, reducing inequality, ensuring openness, love of peace, security, resilience and sustainability of cities and towns, high level of education as well as providing decent work and ensuring economic growth, and etc. All these are the social aspects of sustainable development within the competence of social policy. One of the approaches for ensuring sustainable development is social policy, and it solves the social problems of various categories of the population, expresses the interests of various categories of the population, and promotes the realization of human rights. In the context of sustainable development, it is a social policy to preserve humanity and its resources to meet the necessary needs. The social policy is implemented through the social welfare but the social work is implemented through the provision of standardized social services for those in need. Today, the social policy in Ukraine is participatory, and it's unlike the EU countries.
Its resources are not enough to solve the problems of those who has suffered from the military conflict, pandemic, migration and etc. Therefore, there are significant resources in the field of sustainable development policy and social work. The sustainable development policy comprehensively solves the social problems of the population and provides goals as criteria for solving problems. Social work is aimed at solving the ${ }^{*}$ people situations with socialization, adaptation, rehabilitation, as well as the people who are in difficult circumstances because of life crises, trauma, and other various external circumstances. So, the sustainable development policy can be implemented through social work with servicemen with particular social problems (socialization, adaptation, rehabilitation, integration, etc.) as a result of the military conflict in Ukraine, the pandemic, or the transformation of society.

At the same time, social work with military personnel in the context of sustainable development of society was not considered in the higher educational institutions educational programs. Although it has significant opportunities for this. The training matters for work with military personnel are included into the program of entrance examinations for a master degree in social work of various institutions of higher education. [1, 2]. In the curriculum of individual higher educational institutions is

\footnotetext{
* Corresponding author: trubavina@gmail.com
} 
included such topic as "Social work with representatives of problem groups, military personnel" $[3,4]$. At the same time, the practice reflects that the problems of servicemen and members of their families have increased with their involving into the military conflict in the East of Ukraine and the pandemic. That is why the trained social workers are required today both in the conflict zone and in peaceful communities.

2. The Ukraine's sustainable development strategy should be assessed through the prism of the theory of central places. It has been proven that the theory of central places should be applied in practice not only in relation to the certain settlements, but to the countries. A prime example is the process of human resources formation and development. Conducting statistical analyzing of the initial data of the mentioned process in Ukraine (the dynamics of the population size, its natural movement and the level of unemployment) we have come to the conclusion that real conditions do not correspond to sufficient socio-economic conditions for the formation of the necessary competencies and improvements in people who are suitable for certain activities, as well as the use of the acquired potential of human resources in the process of creating benefits, taking into account the constant changes in the operating conditions. This leads to the migration, which is associated with certain risks to sustainable development [5]. Within the constant changes, in particular, with the emergence of an armed conflict in the East of Ukraine, the spread of COVID-19, we should review the content of training specialists according to the specialty 231 "Social work", with the stages of implementation of John P. Cotter's changes [6, 7]. Despite the fact that more than one hundred of Ukraine higher educational institutions are providing such specialists training, more specialists are required according to the listed changes. The solution to this problem is the organization of advanced training for specialists in the field of social work. Considerable emphasis in the content of the relevant program should be paid to social work with such categories as military personnel, of their families' members, former servicemen, and in particular with those who has become disabled as a result of hostilities. Such advanced training is also advisable for the specialists in the moral and psychological support of military units (deputy commanders in personnel welfare), as they perform social work activities with military personnel within their units. Recently, the discussions regarding the transition from moral and psychological support [8] to psychological support with a method of comparative analysis, focusing on the NATO countries military formations have been taking place in military formations. In our opinion, this is not correct approach [9]. Even before the beginning of the conflict in the East of Ukraine, the sufficient socioeconomic conditions for guaranteed recruitment of military posts in the Ukrainian military units were not created [10]. As a result, there is a lack of proper candidates for military service selection. Thus there is a necessity for socio-pedagogical prevention of maladaptation of servicemen [11] and other measures of social work.

3. The social work is necessary for the military personnel, members of their families, and military units in general the at are located on the territory of Ukraine in specific local communities and interact with them and are not isolated from the society. Therefore, a sustainable development in a society or community is an integral part of sustainable development in military units. The communities and the military units' social services interaction was not traditionally carried out due to the closed nature of military formations. Today, these resources need to be combined, especially in the context of military conflict and pandemic, for their economy and rational use, as well as to achieve the goals 1, 2, 3, 4, 5, 8, 10,16 in the field of sustainable development. The training of specialists for such interaction has not been conducted before in the interests of servicemen and members of their families.

4. There is a discrete issue of military and social work in military units with servicemen and their families' members, as they are involved in the military conflict in Eastern Ukraine. There are dead and wounded combatants, received psychological trauma by servicemen family members as well as social and material problems. Ya. Spodar says that today "one of the priorities of the National Guard Command of Ukraine is the implementation of military and social work aimed primarily at ensuring social protection of wounded servicemen, their family members and killed combatants at combat missions [12]. Officers were not trained for military and social work before the military conflict in Eastern Ukraine. Although some issues of military and social work were included in some academic lectures and textbooks of higher military education establishments in Ukraine [13]. The National Academy of the National Guard of Ukraine and the National University of Defense of Ukraine delivers a discipline on military-social work with military personnel and members of their families. There is also a module at the bachelor degree training in this discipline, but the essence of such work is not clearly defined today. The concept of sustainable development as a guideline for such work has not been applied as well as there is no currently advanced training on this issue.

5. Since the 90 s of the 20 th century, there have been social services consulting centers for young people in Ukraine at the military commissariats, military units and at assembly points. However, these points do not take into account the specifics of our time - the military conflict in the East of Ukraine, its consequences, as well as new social, political and economic realities in Ukraine, and of course the pandemic. Thus, we need to update the content of advanced training of social workers of Ukraine to work with the military personnel and their families in the modern context.

6. Today the State social policy and social work as a direction of its realization through rendering of social services guarantee quality of life of all citizens at the level of the state standards (according to the legislation of Ukraine to all people who are in difficult life circumstances) $[14,15]$.To-day military personnel and their family members have a number of different problems of socialization, social adaptation and social rehabilitation, associated with military professional activities and its consequences (restriction of certain 
human rights, problems with the employment of wives, high-quality education of children in small towns, problems of disability, adaptation of military veterans in civil society, lack of their own housing due to displacement in the country, etc.). The problems of the servicemen necessitated the attention of the leaders of the uniformed services of Ukraine. Their attention is focused on military-social work with their subordinates and members of their families as complementary social assistance and support from the capabilities of their departments. That strengthens the morale of the military. And the servicemen believe that they and their families will not be left without help in the performance of their official duty. These problems are related to health, quality education, decent working conditions, overcoming poverty and poverty in a pandemic and unemployment for family members, gender equality, countering violence, creating conditions for peaceful coexistence in communities, and etc. For example, there are international programs and projects for the Armed Forces of Ukraine personnel social adaptation [15]. In the future, these programs will be implemented only by Ukrainian specialists, who need to be already prepared for this activities. The orientation of Ukraine to the NATO, its social standards for the military today are far from the reality in Ukraine, and if there is no social welfare at this level, there should be, respectively, opportunities for moral and psychological support, military professional activity, that includes military social work.

7. Today we need modern social services of adaptation and rehabilitation in social work with servicemen in the community $[17,18]$. A feature of modern social problems of servicemen is the impact of their participation in the military conflict on their future lives and the lives of their families. Among others there are such matters as problems of rehabilitation of combatants in conflicts in Ukraine and peacekeeping forces, psychological trauma due to tasks in the military conflict zone, which affect members of their families, further life of the families of fallen servicemen, peaceful and successful adaptation of the military in civilian life after demobilization due to injury, discharge from military service, etc. These situations are solved by the social services. Solving such new problems is at the same time solving the problems of sustainable development policy of society, and it is necessary to train specialists for this type of job.

8. Legislation on social services that solve social problems of the population and are implemented through social work defines them as "actions aimed at preventing difficult life circumstances, overcoming such circumstances or minimizing their negative consequences for individuals / families in them. Individuals / families can be provided with one or several social services at the same time"[15]. Difficult life circumstances are "circumstances that negatively affect the life, health and development of a person, the functioning of the family, which the person / family cannot overcome on their own. Factors that can cause difficult life circumstances are: a) old age; b) partial or complete loss of motor activity, memory; c) incurable diseases, diseases that require longterm treatment; d) mental and behavioral disorders, including due to the use of psychoactive substances; e) disability; f) unemployment; g) homelessness; h) person poverty; i) behavioral disorders in children due to parental divorce; j) evasion by parents or guardians of their responsibilities for the upbringing of the child; k) loss of social ties, including while in prison; 1) child abuse; m) gender-based violence; $n$ ) domestic violence, o) getting into a situation of human trafficking; $p$ ) damage caused by fire, natural disaster, catastrophe, hostilities, terrorist act, armed conflict, temporary occupation" [15]. This enumeration allows to clarify the list of users of social services. These can be both veterans and active servicemen and their family members, but unfortunately, the resources of the military-social work of military units are not enough to solve most of these problems, and specialists who are to carry out this work have not received appropriate training. In the field of view of specialists who carry out military-social work, is their social and legal protection and socio-economic support in the Armed Forces of Ukraine [13] and social protection in the National Guard of Ukraine [19]. Other existing problems for military personnel and their families require interaction with social workers in the community. So, the training in identifying such problems and overcoming them in cooperation with attracted specialists is needed, as well as a separate management for advanced training, for which we also need to train specialists, both civilian and military.

9. Many social problems arise when people return from the zone of military conflict to peaceful service, families and peaceful cities. This is no longer their own military unit and it may be a different community. And a social employee needs to be able to offer a person necessary social services. This is a difficult to communicate category of people who are not used to being weak and asking for help, they held weapons in their hands, survived the war. Therefore, peaceful people need to be able to talk and work with them, especially women, who are most of all among social workers. There is no theoretical and practical training for future social workers with servicemen in civilian higher education institutions.

10. It should be noted that certain topics of training in higher education institutions still exist, but advanced training still does not exist. This is due to the fact that for social workers for the military it is differ because of different subordination to the Ministry of Social Policy and to Ministry of Defense. Interaction in the interests of servicemen and their family members is absent in the professional development programs, and servicemen today are not subject of the State social standards of social work. Therefore, there is no advanced training on the problem.

Thus, it is necessary to update the advance training for social work with servicemen of different categories and members of their families as the implementation of the state social policy of Ukraine in the context of the policy of sustainable development of the society. Such training should be provided by both civilian and military higher education institutions. This issue requires separate joint programs of disciplines, and not a separate topic in the discipline or an isolated discipline of only a civilian or only a military institution of higher education. Because 
they need to work in cooperation. Training today should be in a collaborative group for networking and understanding at the community level through the specific people who implement it. The common content is to solve the social problems of servicemen and their families in the context of sustainable development goals, which transfers social work with this category of clients from only social protection, payments, benefits to socialization and social problems through a wider range of social services in interaction with social community workers based on community interaction.

We interviewed thirty-four social workers of social services centers for families, children and youth and nongovernmental organizations in Ternopil and IvanoFrankivsk. They all answered that they did not have enough advanced training in higher educational establishment for such work, and modern approaches and methods of work are needed. Various tried and tested methods of working with servicemen and members of their families are needed too.

We interviewed fifty-six students of the six-year courses of the specialty "Social work" of higher educational establishments in these cities. We asked whether they would be ready to carry out such field of work. Everyone answered that not at all. The reasons for doubting the success of the work were called a young age, lack of experience (professional and life), the complexity of social problems and amount of such problems among servicemen and their families. Although no one said they would refuse to provide social services to this category of clients. This means that the strengthening of such advanced training is obligatory, taking into account gaps and sustainable development ideas. The question arises about the development of such an advanced training program, taking into account the specifics of professional responsibilities and opportunities, state social standards for the providing social services, departmental opportunities, pooling of resources in the community and cooperation in the maintenance of social services, etc. The development of such a program is the purpose of the article.

\section{Research methods and methodology}

Materials for the study are:

1. Legislation of Ukraine on higher education, military education, social work, social services, sustainable development, social policy of the state. The methodological significance is in the orientation of the program, that we will develop, on the best world models of building the educational process, solving social problems and problems of socialization of servicemen and their families, based on the competence approach in education, ideas of sustainable development in social work and military social work.

2. Regulatory framework for military social work in various law enforcement agencies [19, 20]. Today, the solution to the problem of improving the quality of officers of the security forces of Ukraine service depends on the human factor, moral and psychological support of the service, the microclimate within the military unit and the creation of various conditions for service, including social, economic, material, psychological, medical, etc. The unit commander is unable to solve all the social problems of his subordinates both of an individual and the entire unit. To help them, the positions of deputy commanders in welfare have been implemented. So they are responsible for such areas of work as military social work with personnel. He also carries out morale and welfare work with personnel. There is no definition of the essence of military social work in the legislation today. Therefore, the training of specialists for military social work should be carried out taking into account the regulations of military structures, as well as basic education, science, theory, technology, methodology. Note that the regulations are already based on the idea of sustainable development for goals $1,2,3,4,5,8,10,16$. But their implementation at the level of practical social work is absent.

3. Characteristics and list of both general and special social needs and problems of servicemen and members of their families [16, 17, 21-27]. Older people, children with disabilities and others in need of outer support and assistance are particularly vulnerable in pandemics and military conflict, and need more support and assistance in their everyday lives. Thus, goal 10 in the field of sustainable development suggests that, in a pandemic, "Refugees and migrants, as well as the older people, people with disabilities and children, are particularly at risk to be neglected. In addition, hate speech against vulnerable groups is growing" [28]. These are essentially tasks of military social work and social protection, which coincide with the goals of sustainable development. The military conflict in Ukraine has significantly increased the number of social services users. The military themselves have already understood the necessity of social work with their colleagues and members of their families (assessing by modern regulations on the problem of military formations. The list of these problems) [21-27]. Also the military conflict made it possible to determine the current tasks and content of military social work and social work with servicemen and their families such as social adaptation, social prevention, social rehabilitation, social support, management of social services implemented through complexes of social services;

4. Social work with servicemen theoretical and methodological principles developed in the world and in Ukraine to solve their social problems. Thus, Joel F. Handler [29] says about British model of integrated complex family services at the local community level as a rigid set of social services. We believe that they still need some alternative, choice, taking into account the characteristics of customers and their families. But it is valuable to combine the diagnostic model of social work with social policy and management of social services in the community. This combination is not established in Ukraine. The social services are centralized according to standards and categories of clients. In the UK, all social services must comply not only with public social policy, but also be scientifically proved, useful in a particular community. Communication within the community is especially important [30]. The UK uses different approaches to social work, including intervention, 
medical social work, group theory and work with them, the idea of group development (which coincides with our idea of family development and organizational development), problem-oriented and environmental approaches to social work [31], and that provides for individualization and differentiation in the provision of social services. But the client cannot determine and choose the set of services. It is the object of services. Since 2001, Ukraine has been working with clients as subjects of social services, only in certain identified crisis cases as an object ("self-help" and "crisis intervention") [32]. Valuable in the UK is the methodology of working with the families of servicemen who have been involved in military conflicts "FOCUS". This methodology reduces military personnel and their family members' anxiety and depression and provides a long-term positive result. A family-centric approach to socio-pedagogical work with the family is useful for working with servicemen' families. It considers socio-pedagogical services as a subsystem of social services, as the main for learning a new positive model of behavior of family members, and as creating conditions for implementation family rights in society and community and family member rights in the family [32]. This requires considering working with a serviceman, taking into account the integrity and rights. We also relied on Carl Castro and Sanela Dursun's book "Reintegration of the Military Veteran" [33], which reveals the views of experts from all over the world on the problem, offers a methodology for assessing the veteran's needs, and a roadmap for achieving the best social services in the future. Also the description of the program of transition from military service to civilian life, the role of the family, the public, medical institutions in this process is valuable in this study. In the United States, the need for a program-targeted approach to the reintegration and provision of social services has been proven [34]. This is also confirmed by our work as a consultant in the Ukraine central state authority on social work in 20002015. We worked on the following state comprehensive and targeted programs for social support of the family: "Social support of the family"; "Social support for disadvantaged families"; "Social support of orphanages and foster families"[32], and implemented them. But there are no separate programs of social work to support servicemen and members of their families in Ukraine. We also relied on approaches to the social services for servicemen and their families in different countries. Among them there are social services and social programs in a peaceful life and in a conflict of Ukraine, the Great Britain, the USA, France and Germany, which use integrated, comprehensive, problem-oriented approaches, the theory of strengths, "self-help" and "crisis intervention"), took into account the results of the analysis of theories of social work in Ukraine $[32,35]$.

5. World and local experience on the problem. Thus, the goal of the "social service of the Swiss Armed Forces is to reduce social disparities. Assistance takes the form of personal advice on family, financial or legal matters. Topics include labor law (protection against dismissal, continued payment of partial wages), income replacement, health insurance contributions, debt collection and others.... assistance is provided through information, consulting, support, mediation and financial support"[36]. At the same time, the Swiss Armed Forces social service is a specialized agency of the armed forces that provides advice on social issues. It is a military function, not civilian work [38]. In the USA, Canada there are Centers and departments in the Ministries of Defense for work with personnel and veterans, researches of their social rehabilitation, social work with families of combatants are carried out, new approaches and strategies on their social adaptation to civilian life are developed, developed federal programs for the disabled and veterans, conducted research on the psychological and social characteristics of peaceful service and during hostilities [35]. Institutional forms of providing social services to servicemen and members of their families in the world and in Ukraine today are service hubs, integrated support centers, social services and their specialized formations, rehabilitation centers, personnel departments, etc. [39, 32]. Social service centers for families, children and young people have some experience in adapting servicemen to the conditions of service, for example, their psychological boarding on a Ukrainian Navy vessels. The Veterans of Military Conflict Department exists in the Ministry of Internal Affairs of Ukraine. It provides practical social assistance to veterans and members of their families. At the National Guard of Ukraine units, the military social work is carried out essentially as social welfare [19]. All participants in hostilities in Ukraine are provided with social welfare in accordance with the law [40]. It should be noted that military and social work in military units today can be carried out according to normative documents not only by deputy commanders in welfare. The legal acts allows to conduct such type of work with families, children and youth by specialists, such as the authorized bodies engaged in social work with families, children and youth; social work specialists; associations of citizens, charitable, religious organizations; legal entities and individuals that provide social services to families, children and youth; volunteers in the field of social work with families, children and youth (law on social work). Therefore, their experience and resources are appropriate for social work with servicemen. Military and social work is the sphere of activity of the military, but they can interact with other subjects of social work in the interests of solving social problems of the militaries and members of their families, the community in which the military unit is located.

6. Scientific sources on social and military social work, which clarify its essence, purpose, scientific basis. According to the legislation of Ukraine [14], social work is understood as "professional activity aimed at preventing, minimizing negative consequences and overcoming difficult life circumstances of families, children and youth, strengthening their ability to realize their own life potential". This totally applies to officers and their families and is in line with the sustainable development goals $1,2,3,4,5,8,10,16$. Savitsky [41] considers that military social work, as well as social work in general, should be considered from such several points of view as: a) it is a kind of human activity - it concerns a person whose life in some way affects the army; b) it is the science of the laws of military social work, its 
methods, principles, technologies; c) it is a science that sheds light on practical and transformative charitable practice in the plane of military society; d) it is an academic discipline that, based on the points of the theory of social work, its content shows the peculiarities of the practice of social services in the military social environment.

We agree with this meaning of social work, and it allows us to apply to military and social work all the theoretical principles and methodological developments of social work, to take into account the problems of servicemen and their families as well as methods of training social workers to train officers who practice military and social work. The same researcher defines that "military social work is the science of formation, development, charity in the army, the organization of social services and the providing of appropriate social assistance to servicemen, as well as all those who have or had some relationship to the defense of the Motherland" [41]. Thus, this definition emphasizes the purpose of military and social work, as well as the criteria for defining its objects. They are the active servicemen and those who were involved in military service. There are other points of view on this concept.

Military and social work today is understood in the Russian Federation as "a system of conceptualtheoretical, political-legal and organizational-practical measures of the state and non-state institutions and authorities to meet the needs, interests and benefits of servicemen discharged from military service and their families in the social sphere of life. It serves, on the one hand, as an instrument and conductor of the state's social policy in the military field, and on the other hand, as a concretization and addition of social policy to the activities of civil society institutions to realize specific social needs and interests, rights and freedoms, guarantees and benefits of military society [42]. We do not agree that military and social work is limited to those servicemen who are discharged to the reserve.

Today a number of acting servicemen also need social support and assistance due to the circumstances described above. But the idea of combining in the system the measures of different levels and spheres of activity that implements a systematic and multidisciplinary approach in social work is useful. Today, the Armed Forces of Ukraine interprets social work as "socio-legal, informational and organizational measures regarding promotion of the implementation of the rights, benefits, social assistance and appropriate compensations for servicemen and employees of the Armed Forces and other military formations of Ukraine, for the members of their families, by creating social conditions and guarantees in military and labor collectives which would provide their normal vital activity, conscientious and high-quality performance by servicemen and civilian personnel of the functional and service duties assigned to them" which is established by the legislation of Ukraine and other legal acts, thus military social work is divided into social and material maintenance and socio-legal protection [43].

Sharing the opinion of the authors on the need for social work to create social conditions and guarantees in military social work, we note that social services in
Ukraine according to the legal acts are broader than both social welfare and legal protection and social and material security. Moreover, prevention measures are the part of military social work that includes not only educational but also social, psychological, legal content, and so on. Today the spectrum of social problems of servicemen and members of their families is bigger than 7 years ago. Therefore, the content of military social work requires improvement. There is an opinion that in Ukraine "military social work is an integral type of social work and military management, specifically military education, work on humanitarian issues" [41]. And it is true in terms of working with personnel. However, we believe that it should include issues of social management and management of social services, interaction in the community in the interests of servicemen and members of their families. Therefore, it is the way of sustainable development ideas implementation. Families of servicemen also have economic problems today. The Coronavirus pandemic, which has caused many family members of military personnel to lose their jobs, is already a challenge in military camps, where wives often work unprofessionally or are underemployed. Also, there is not much work for young people. A serviceman becomes the only working person in the family, not having the right under the legislation of Ukraine to work part-time anywhere except the scientific and teaching spheres. Therefore, we need to work to support and help family members to prevent impoverishment and create decent living conditions for ourselves and our children. These are goals $1,2,3,4,8,10$ in the field of sustainable development.

7. The philosophy and sociology studies of war and peace [44-52] determined the socio-philosophical foundations of military and professional activity and the purpose of military service during war and peace, which affects the problems of users of social services, features of their provision, content, technology and methods of social work and military social work in subdivisions and units. The philosophy of war and peace influences the peculiarities of training servicemen for peaceful service and in combat, the peculiarities of social management in military units and social work itself. The philosophy says about number of issues to be solved such as a need to solve a set of problems of servicemen in different conditions, the problems solution, a human factor as the basis of victories and defeats and social conditions for this, a problem-oriented approach in social work in combat, a need to form reliability and resilience of servicemen through competency and activity approaches as well as special training of social workers to provide social services in different conditions to the different categories of servicemen and their families [53, 54].

8. Educational programs of civilian institutions of higher education that train specialists in social work [1-4]. Today these programs almost don't take into account the problems of servicemen and members of their families as subjects and objects of social work. But they provide theoretical and practical foundations for working with different categories of the population, form professional competencies for this purpose.

9. Educational programs of higher military 
educational institutions of Ukraine (the National University of Defense of Ukraine (NUDU), the National Academy of the National Guard of Ukraine (NANGU)) and of the world. The analysis of these programs shows the implementation of a competency-based approach in higher military educational establishment. However, there is no interaction with community social workers, sustainable development goals, modern social problems of servicemen and technologies and methods of solving them, world experience on the problem in programs of disciplines related to military social work. In the discipline "Information and propaganda support of military missions and operations", there is a module on military social work, but it does not take into account the issues of interaction with social services of the community and sustainable development. We believe that social work is a separate area of the officer's work, as it includes a range of social services and types of work aimed at solving social problems, of which educational and pedagogical problems are only a small part of the whole range of social problems of servicemen and these problems require a solution with the help of a complex of social services. That is, not educational work should include social work, and military social work can have an educational approach. The reasons for this are that the concept of socialization of the personality in pedagogy is broader than education, and includes it as a purposeful factor in the development of personality, as one of many factors that affect the development of personality and determine it. The Swiss experience of training social workers for the military forces is interesting. It is carried out as advanced training on the basis of education in social work, social sphere and military training (conscript schools). The training course for a military social worker is a fascinating three-week training course (technical course) that prepares for the specifics of social work in the army, as well as for the tasks and activities in favor of social service in the army. After the course an officer is appointed as a specialist. The course is conducted in conjunction with the army pastoral care and the army psychological and pedagogical service" [38]. But this course also did not provide preparation for interaction in the community and there is no focus on the goals of sustainable development. But the Swiss army has great social achievements in terms of social protection of servicemen and at the same time takes care of professional social work in terms of morale and psychological condition of the servicemen. In Germany, the servicemen emerging problems are solved by the social workers from the reserve officers who received the second higher profile education after dismissal at the expense of the Ministry of Defense [55, p. 218].

10. Basics of gender theory in military units. [56] 10\% of women took part in hostilities in Eastern Ukraine. Since 2012 there have been female cadet sat higher military educational institutions. There are women who take up military posts. Therefore, it is necessary to take into account their points of view in decisions making concerning of creating social conditions for successful service. In addition, gender-based social work will help prevent family violence, sexual harassment at service, and gender education for men and women. Goal \#5 of
Sustainable Development states that today, "The coronavirus outbreak exacerbates existing inequalities for women and girls in all areas, from health and economy to security and social protection", "the data show that since the moment of pandemic outbreak beginning violence against women and girls, especially family violence, intensified." Women's economic freedom is the basis of social prevention of family violence. Therefore, a gender approach should be included in the program for the provision of social services.

The methods of our study are following: comparative analysis, theoretical analysis of sources, generalization, survey, observation, modeling and synthesis.

\section{Results}

In order to develop advanced training programs for working specialists of social services and the servicemen we had to solve several tasks. Among them there are: 1) to clarify the essence of the concept of "military social work"; 2) to determine the users of military social and social work services with servicemen and members of their families; 3) to substantiate and determine the theoretical foundations of such social work and the construction of such programs (in the context of sustainable development); 4) to develop advanced training joint program for social workers of the community and the servicemen who are responsible for this type of job in their units. As there is no legislative definition of this term in Ukraine as well as its unique understanding, we applied to native and international experience in solving the problem. In the United States, military social work has its own organizational structure, regulations, service delivery standards. It provides educational and qualification requirements for military social workers, specific professional training and following certain ethical principles $[35,57]$. The military social workers positions were introduced at the United States Department of Defense. At the Department of Veterans' Affairs the positions were established to work with veterans. That is, in the United States, they work both with those servicemen who serve, and with those servicemen who are already retired [57]. At the same time, a profile approach is also interesting. It combines United States civilian social workers and servicemen and defines military social work as "continuous activities, political and administrative measures, and advocacy, including prevention, treatment and rehabilitation services for social clients, veterans, their families and the communities in which they live" [35]. This approach is multilevel and partnership-based to provide services to the military and their families. At the same time, it singles out military social work as a separate area of social work with servicemen. But it does not fully take into account the Ukraine realities and its current problems because it is permanent, and in Ukraine there is an acceptable concept of "help for self-help" in social work [32], which is limited in time and provides a gradual transition from crisis to development. Therefore, we agree with this approach in combination with other approaches that are appropriate in our country. 
Today in Ukraine, "the purpose of social work in the context of military service is to restore the physical and mental strength of those who are assisted, to adjust the personal attitudes of clients, teaching them to properly perceive the coercive aspects of their lives; to introduce elements of social justice into the framework of subordinate attitudes which are typical of military service" [58, p. 149-156]. This focuses to social rehabilitation (recovery), social prevention, which are the types of social work, psychological and ethical approaches. But social work is needed by those who are in the conflict zone, veterans and the disabled, their families, and those who are currently serving in peaceful areas. The conflict in Eastern Ukraine leads to the social problems: deaths of servicemen, their injuries, family distance, psychological trauma and mental and behavioral disorders, right up to alcoholism, drug addiction, smoking, etc. At the same time, family members themselves take upon the father burden who performs tasks for a long time in a military conflict zone. This is a long-term stress for the family and each of its members. In addition, the coronavirus pandemic leads to problems with psychological state, anxiety, even suicide, alcoholism and drug addiction. This is a double burden on the family, which requires special psychological and social support and assistance to officers and their families, the promotion of a healthy lifestyle, and so on.

Therefore, Goal \#3 in the field of sustainable development says about a need to help maintain the mental health of people during a pandemic and coincides with the goal of social prevention of negative phenomena as a sphere of the social work content. Preventive and rehabilitation approaches are thus important for social work with servicemen and their families. This coincides with the opinion of $\mathrm{Yu}$. V. Brindikov [17], who was engaged in social rehabilitation of ATO soldiers. N. S. Oleksiuk [18] has proved a need for a socio-pedagogical approach in work with the servicemen families. This approach combines social assistance and support along with showing positive patterns of behavior in the family.

The military conflict itself is a threat to sustainable development and requires the social support of those who are affected and involved. "The best form of response will be to neutralize direct threats by actions which are commensurate with those threats, while protecting human rights and the rule of law", the UN Secretary-General claimed [60]. At the same time, human rights must be also ensured in this situation because they preserve human dignity [60]. This means relying on the theory of human rights and a human rights-based approach in social work and makes military social work necessary on this basis to focus on working with those military who are involved in the conflict in Eastern Ukraine. We have proved that socio-pedagogical work as a component of social work is essentially human rights-based like creating conditions for the realization of human rights, showing a new positive model of behavior [32]. In addition, "in relation to a serviceman of service for a fixed period, military social work helps to discharge his/her duty with dignity, for an officer it contributes to family well-being, for a military retiree it provides a dignified existence, etc." [41] This means the differentiation of military social work and targeted provision of social services with different content and methods, technologies. How to implement it in the conditions of a conflict and pandemics, what criteria for providing social services should be guided, how to choose the priority problems to solve in the conflict zone, to find resources and other issues are the problems for many social workers and commanders. They need to be taught this on the basis of a problem-oriented approach and human rights theory. Note that officers often change their place of service, and this requires both their adaptation to new conditions of service and life, and adaptation in the community and micro-environment of their families.

This process is always difficult and long, painful and can be resolved more calmly if you use the services of social workers. Goal \#8 of sustainable development says about the necessary socio-economic measures for sustainable development in the conditions of a pandemic: “... helping people to overcome trials through social protection and basic services; promoting social cohesion and investing in community-based resilience and response systems." These are multidisciplinary, organizational and resource-based approaches in social work with the servicemen. Since our advanced training program is designed for adults, not students, it should be developed taking into account an androgynous approach which requires learning from the experience of students, taking into account their views in learning; today a competence approach is the basis of education, and an activity and student-oriented approach and a personality-oriented approach are the basis of all learning, they take into account the views and wishes of learners, learning in activities. All this requires a training form of adult education, the features of which we have explored and taken into account in developing the program. In addition, a digital approach for learning the program material is required, as the presentation of information for learning is the basis of a conscious activity, and the digital form of its presentation better contributes to the implementation of learning principles (clarity, science, connection with life, etc.), accelerates learning.

On the basis of the stated information, we can make such generalizations on the $1^{\text {st }}, 2^{\text {nd }}$ and $3^{\text {rd }}$ tasks of the article as a basis for performance of the last task. Military social work is the direction of implementation of social policy with servicemen and the members of their families, which is carried out through the provision of social services on counseling, information, support, assistance, self-help, advocacy, organizational measures, social protection in various types of social work (social prevention, social rehabilitation, social support, social services, social management) and benefits, social guarantees of the state. It should be noted that state standards for the provision of social services in Ukraine also belong to the state social guarantees. Social work is subordinated to social management in the military team, solves social problems of servicemen and is carried out by a unit deputy commander on work with personnel. Its purpose is to create social conditions in the military unit to perform military and professional tasks at the highest level by servicemen, to realize their rights and legitimate interests in everyday life and service, to meet the specific needs of servicemen and their benefits and to solve their 
special social problems (socialization), adaptation, integration, etc.). Social work with servicemen is a social work, the object of which is the servicemen and the members of their families, it solves their problems of socialization and adaptation, rehabilitation. It is carried out as the provision of social services to people in difficult life circumstances.

The objects of military social work are: servicemen on active service and the members of their families; in reserve servicemen, retired, lost their ability to work; the family members of lost servicemen; all members of military units. The subjects of military social work are: military personnel commanders and military personnel deputy commanders of military units, as well as servicemen and the members of their families. In social work, these are the same objects as in military social work, but only those that are in difficult life circumstances. We consider the objects of both types of social work at the same time as its subjects, except the cases of family violence, child abuse, threats to life and health of family members and children.

Based on the theoretical foundations of the social work in military aspects and the social work with the military, we have identified the following scientific approaches:

1) Philosophical approaches: the persistent development of society, ethical area, philosophy of war and peace, human development;

2) General scientific approaches: the theory of human rights, resources, optimization, multidisciplinary; organizational, systemic, political, comparative and axiological approaches;

3) Specific scientific approaches: the human rightsbased approach, social policy, socio-pedagogical (environmental, family-centered, personal), programtarget approach, pedagogical (the theory of activation, theory of team, the dialogue of cultures, theory of participation, personality-oriented education, pedagogical support, facilitation);

4) Approaches of social work: the problem-oriented and psychological oriented approaches (humanistic, functional, behavioral and cognitive theories, catalytic and client-centric models of social work), approach of sociological focus (the systemic theory of social work, theory of social roles, theory of stigmatization), complex oriented method (intervention (crisis intervention), a model which is oriented on a task or a problem, a self-help aid); the preventive, rehabilitative, profile and integrated approaches, theory of strong points. Its content is a variety of social services, which are realized in a comprehensive manner at the social prevention, social support, social management, social protection, social services and social rehabilitation.

Of great importance is the consideration of scientific approaches and theoretical foundations: the theory of persistent development; student-centered, informational, digital, competence, androgynous and personalityoriented approaches, theories of educational content, activation of education process. It presents during the development and realization of a professional development program for social workers who help servicemen and members of their families, and the military who work in military units in the context of the military social work.

In view of the foregoing and exploring the professional development programs for social workers and servicemen [1-4,60 and others], we can formulate the purpose and tasks of the professional development programs for social workers to work with the military in the context of persistent development ideas. The purpose is to develop the professional competencies of social workers and officers in military units to occupy the social work with servicemen in coordination in the community. The tasks are to develop the professional competences of social workers and military officers who deliver the social work (the ability to analyze mental properties, states and processes, processes of military personnel socialization, prevention of social risks, difficult life circumstances, prevention and resolving of social conflicts in the military staff, serviceman's family, divorce prevention, ability to understand the organization and functioning of the social protection system and social services in the community and at the military formations, ability to study the social problem of the military and their families, to appreciate their problems, requirements, specifics and resources, ability to develop effective methods and ways to solve problems, ability to give efficient social services to the military, capability to cooperate with community members, capability to adhere to ethical principles of social work, ability to justify, to make professional decisions as regards clients of social work and to take responsibility for their consequences) and general competencies (ability to use the information and communication technologies, ability to be critical and self-critical, ability to work as a team and alone, ability to communicate with members of other professional groups).

Features of the program are the simultaneous training of social workers and the military of the community; focus on social services in the context of persistent development: goals $1,2,3,4,5,8,10,16$; focus on the human factor and cooperation, the subjectivity of the individual, human rights and the improving communications in the community, exchange of resources and social services; the theory of social work with the military is combined with exercises, the experience of specialists (ideally as training forms of its realization), the using of media education tools and distance learning technologies, a work in microgroups. This program is developed for professionals of the higher education in social work and military support. The program is designed for 30 hours of classes and 60 hours of individual practice, in total of three credits. It highlights the content of the professional development program for social workers and the military "Social work with the military and the social work in military aspects in the context of the persistent development of society" (See table 1).This development program was discussed at the Departments of Pedagogy and Pedagogical Management; Social work, Special education and socio-cultural management and after approbations it was posted in the website of Ternopil Volodymyr Hnatiuk National Pedagogical University. It was socially advertised among social workers in the region, in the military units. Its content and 
methodological materials were developed before its implementation and people were interested in. Nowadays there are methodological and organizational studies to introduce the realization of the program using the distance learning tools. Professors (who will realize it) have graduated the distance studding courses of the media education and mastered digital tools of interactive teaching. They have learnt methods of their application during the distance education. The first lessons will be

Table 1. The curriculum of the development program "Social work with the military and the social work in military aspects in the context of the sustainable development of society".

\begin{tabular}{|c|c|c|c|c|c|}
\hline \multirow[b]{2}{*}{ № } & \multirow[b]{2}{*}{ Name and content of training modules } & \multirow[b]{2}{*}{ Hours } & \multicolumn{2}{|r|}{ For } & \multirow[b]{2}{*}{ Teacher } \\
\hline & & & Classes & $\begin{array}{l}\text { Independent } \\
\text { work }\end{array}$ & \\
\hline \multicolumn{6}{|c|}{ Module 1 "Digital tools for teaching of social work" } \\
\hline 1 & $\begin{array}{l}\text { Media education tools and distance technology tools in the } \\
\text { educational process }\end{array}$ & 3 & 1 & 2 & $\begin{array}{l}\text { Petryshyn L.Y., Medvid M.M., } \\
\text { Trubavina I.M., Meshko H.M. }\end{array}$ \\
\hline \multicolumn{6}{|c|}{ Module 2 "Theoretical foundations of social work with the military and members of their families" } \\
\hline 2 & $\begin{array}{l}\text { The military and members of their familiesas subjects and } \\
\text { objects of the social work and the social work in military } \\
\text { aspects. }\end{array}$ & 3 & 1 & 2 & $\begin{array}{l}\text { Petryshyn L.Y., Medvid M.M., } \\
\text { Trubavina I.M., Meshko H.M. }\end{array}$ \\
\hline 3 & $\begin{array}{l}\text { The sustainable development policy and social policy towards } \\
\text { the military and members of their families in Ukraine }\end{array}$ & 3 & 1 & 2 & $\begin{array}{l}\text { Petryshyn L.Y., Medvid M.M., } \\
\text { Trubavina I.M., Meshko H.M. }\end{array}$ \\
\hline 4 & $\begin{array}{l}\text { Theories of social work in relation to the military and } \\
\text { members of their families }\end{array}$ & 3 & 1 & 2 & $\begin{array}{l}\text { Petryshyn L.Y., Medvid M.M., } \\
\text { Trubavina I.M., Meshko H.M. }\end{array}$ \\
\hline \multicolumn{6}{|c|}{ Module 3. "Practice of social work with the military and members of their families in the community" } \\
\hline 5 & $\begin{array}{l}\text { The world and internal experience of social work in the } \\
\text { community with the military and members of their families }\end{array}$ & 6 & 2 & 4 & $\begin{array}{l}\text { Petryshyn L.Y., Medvid M.M., } \\
\text { Trubavina I.M., Meshko H.M. }\end{array}$ \\
\hline 6 & $\begin{array}{l}\text { The cooperation in the community as a base for solving social } \\
\text { problems of the military and their families. }\end{array}$ & 3 & 1 & 2 & $\begin{array}{l}\text { Petryshyn L.Y., Medvid M.M., } \\
\text { Trubavina I.M., Meshko H.M. }\end{array}$ \\
\hline 7 & Project presentations, program results & 9 & 3 & 6 & $\begin{array}{l}\text { Petryshyn L.Y., Medvid M.M., } \\
\text { Trubavina I.M., Meshko H.M. }\end{array}$ \\
\hline
\end{tabular}

\section{Discussion}

Our development program takes into account the purposes of the sustainable development, the main modern problems of the military from the different structures of Ukraine, the foreign and internal experience of social work with them, based on the theoretical foundations of such work. The foundations are determined taking into account the mentality of Ukrainians, the best international experience of the education and the valid legislation about the social work and education in this area, pay attention to thoughts of main stakeholders in this way of educational activities, the experience in developing and realizing such programs in civil and military higher educational establishments in Ukraine.

It should be noted that there is not any social work with the military or the social work in military aspects in the Republic of Poland. But there are the NATO social standards for the military. Seminars for advanced training of the military personnel are conducted in Ukraine by international organizations (UN-women and their partners to introduce a gender approach in the educational process of higher educational establishments). But this is only a separate aspect of our program content. The European University Continuing Education Network held a scientific-practical conference with the simultaneous short-term professional development "Actual Problems of Psychology, Sociology, Social Work and Professional hold after January 14, 2021. It will be based on Ternopil Volodymyr Hnatiuk National Pedagogical in the Ternopil region. The addition of media competence elements as a part of the development course to master tools and the real training by students (use to divide to small groups for discussion, to assume by everyone, to do tasks and etc.) is another successful condition during the pandemic. The curriculum of the program is given in the Table 1 [61]. 
their families, sustainable development ideas and the social policy, the necessity in the community using the set of scientific approaches for such social work. The program consists of three modules: "Digital tools for teaching of social work", "Theoretical foundations of social work with the military and members of their families" and "Practice of social work with the military and members of their families in the community". It is required 30 hours of classwork and 15 hours of independent work. It is based on a set of scientific approaches to professional development of social workers and the military in the social aspects who already have a higher education and a work experience. The conditions for its implementation during a pandemic are the teachers' development in the area of media tools for education and distance technologies for interactive learning. In this situation they should also accomplish another using method, cooperation in the development community some social services; the social advertising of the program among potential listeners. For students, it is a condition for the successful professional development during the studying of the course about media education tools which will be needed in the developing. Further research into the chosen problems looks promising as the development and implementation of specialization disciplines in higher educational establishments as a choice of studying the social work with the military and members of their families, the social work in military aspects for cadets and students.

\section{References}

1. Prohrama profesiinoho vstupnoho testuvannia $\mathrm{Z}$ sotsialnoi roboty. Fail - 7.13010201 Stupin mahistra za spetsialnistiu "Sotsialna robota" (Program of professional introductory testing in social work. Field - 7.13010201 Undergrad degree in "Social work"). http://luguniv.edu.ua/wp-

content/uploads/2015/04/fvv_s_soc_work_2015.pdf (2015). Accessed 25 Oct. $20 \overline{2} 0$

2. Prohrama vstupnoho fakhovoho vyprobuvannia (spivbesidy) z Sotsialnoi roboty dlia hromadian Ukrainy, inozemnykh hromadian ta osib bez hromadianstva, pry vstupi na navchannia dlia zdobuttia stupenia "Mahistra" na bazi zdobutoho stupenia bakalavra/ osvitnoh rivnia spetsialista haluz znan: 23 Sotsialna robota spetsialnist: 231 Sotsialna robota osvitni prohramy : sotsialnyi zakhyst naselennia, sotsialna robota (Program of professional introductory test (interview) on Social Work for citizens of Ukraine, foreign citizens and stateless persons, when entering the study for a Master's degree on the basis of a bachelor's / undergrad degree in the 23 field of knowledge "Social work specialty", specification 231 "Social work: educational program - social protection, social work"). https://vstup.npu.edu.ua/images/pk$2020 / \%$ D0 $\% 9 F \% D 1 \% 80 \% D 0 \% B E \% D 0 \% B 3 \% D 1$ $\% 80 \%$ D0\%B0\%D0\%BC\%D0\%B8_\%D0\%B2\%D1
$\% 81 \% \mathrm{D} 1 \% 82 \% \mathrm{D} 1 \% 83 \% \mathrm{D} 0 \% \mathrm{BF} \% \mathrm{D} 0 \% \mathrm{BD} \% \mathrm{D} 0 \%$ B8\%D1\%85 \%D0\%B2\%D0\%B8\%D0\%BF\%D1\%8 0\%D0\%BE\%D0\%B1\%D1\%83\%D0\%B2\%D0\%B0 $\% \mathrm{D} 0 \% \mathrm{BD} \% \mathrm{D} 1 \% 8 \mathrm{C} / \% \mathrm{D} 1 \% 81 \% \mathrm{D} 0 \% \mathrm{BE} \% \mathrm{D} 1 \% 86$ $\% \mathrm{D} 1 \% 96 \% \mathrm{D} 0 \% \mathrm{BE} \% \mathrm{D} 0 \% \mathrm{BB} \% \mathrm{D} 0 \% \mathrm{BE} \% \mathrm{D} 0 \% \mathrm{~B} 3$ $\% \mathrm{D} 0 \% \mathrm{~B} 8 / \% \mathrm{D} 0 \% \mathrm{BC} \% \mathrm{D} 0 \% \mathrm{~B} 0 \% \mathrm{D} 0 \% \mathrm{~B} 3 / \mathrm{n} / 231 \mathrm{C}$ $\% \mathrm{D} 0 \% \mathrm{BE} \% \mathrm{D} 1 \% 86 \% \mathrm{D} 1 \% 96 \% \mathrm{D} 0 \% \mathrm{~B} 0 \% \mathrm{D} 0 \% \overline{\mathrm{BB}} \%$ $\mathrm{D} 1 \% 8 \mathrm{C} \% \mathrm{D} 0 \% \mathrm{BD} \% \mathrm{D} 0 \% \mathrm{~B} 0 \% \mathrm{D} 1 \% 80 \% \mathrm{D} 0 \% \mathrm{BE} \%$ D0\%B1\%D0\%BE\%D1\%82\%D0\%B0_\%D0\%BC\% D0\%B0\%D0\%B3.pdf (Kyiv. 2020), Accessed 22 Oct. 2020

3. Robocha prohrama $z$ dystsypliny «Sotsialna robota $z$ riznymy hrupamy kliientiv», stupin vyshchoi osvity - bakalavr, haluz znan - 23 Sotsialna robota, spetsialnist - 231 Sotsialna robota, osvitno-profesiina prohrama - sotsialna robota (Educational program on the subject "Social work with different groups of clients" Degree bachelor, Field of knowledge 23 Social work, specification 231 "Social work: educational program - social work"). https://www.wunu.edu.ua/opp/uf/socialna_robota/so cialna_robota_bakalavr/soc_robota_z_riznum_hrup klientiv/work.pdf (2019). Accessed 23 Oct. 2020

4. Navchalno-metodychnyi kompleks navchalnoi dystsypliny "Sotsialna robota $\mathrm{z}$ riznymy hrupamy kliientiv" (Educational and methodological complex of the educational discipline "Social work with different groups of clients"). https://nubip.edu.ua/sites/default/files/u188/rp_3k_s oc.rob._z_riznimi_grupami_kliientiv.pdf (Nubip, Kyiv, 2020). Accessed 24 Oct. 2020

5. M. Medvid, O. Komisarov, O. Merdova, Review of thetasksof formation and progress of human resources in the sustainable development strategy of Ukraine in the light of central placet heory: Baltic Journal of Economic Studies 4 (2), 134-140 (2018). doi:10.30525/2256-0742/2018-4-2-134-140

6. M. M. Medvid, A. V. Babichev, V. M. Demianishyn, Yu. I. Medvid, A. G. Bukhun, Poperedu zmin u viiskovykh systemakh vyshchoi osvity ta profesiinoi oriientatsii (Ahead of changes in the military systems of higher education and vocational guidance). Visnyk of Cherkassy University: pedagogic sciences 14, 7687 (2016)

7. J.P. Cotter, Ahead of change (OlimpBusiness, Mocsow, 2016)

8. Boiovyi statut mekhanizovanykh i tankovykh viisk sukhoputnykh viisk Zbroinykh Syl Ukrainy (Combat charter of mechanized and tank troops of the land forces of the Armed Forces of Ukraine) (AFU FM. Part II. Batalon, rota (Battalion, company). https://drive.google.com/file/d/1ZLqCUA1Lfe992L kb2kBP0zwwkh1h2do3/view (Varta, Kyiv, 2016). Accessed 25 Oct. 2020

9. M. M. Medvid, P.O. Ivashchenko, M. V. Zverev, Yu. I. Medvid, Metodyka porivnialnoho analizu vyvchennia dosvidu derzhavnoho upravlinnia na 
prykladi sotsialnoho zakhystu viiskovosluzhbovtsiv. (Methods of comparative analysis of the study of public administration experience on the example of servicemen social protection). Chest i zakon 2 (73), 107-114.

http://chiz.nangu.edu.ua/issue/viewFile/12552/6666 (2020). Accessed 30 Oct. 2020

10. M. M. Medvid, Vyznachennia dostatnikh umov harantovanoho komplektuvannia viiskovykh posad u myrnyi chas (Determining sufficient conditions for guaranteed staffing of military positions in peacetime). Chest i zakon 2(45), 44-49 (2013)

11. T. M. Sergienko, M. M. Medvid, O. D. Cherkashyn, Teoretychni osnovy sotsialno-pedahohichnoi profilaktyky dezadaptatsii kursantiv molodshykh kursiv vyshchykh viiskovykh navchalnykh zakladiv (Theoretical bases of social and pedagogical prevention of maladaptation of cadets of junior courses of higher military educational institutions). Zbirnyk naukovykh prats Khersonskoho derzhavnoho universytetu. Pedahohichni nauky 81 (2), 214-219 (2018)

12. U Natshvardii stvoryly komitet dlia pidtrymky simei zahyblykh voiniv (The National Guard has set up a committee to support the families of fallen soldiers). https://ngu.gov.ua/ua/news/u-nacgvardiyistvorylykomitet-dlya-pidtrymky-simey-zagyblyhvoyiniv-0 Accessed 28 Oct. 2020

13. V. I. Aleshchenko, Viiskovo-sotsialne upravlinnia: teoriia ta praktyka (Military and social management: theory and practice) (NUDU, Kyiv, 2019)

14. Zakon Ukrainy "Pro sotsialnu robotu $\mathrm{z}$ simiamy, ditmy ta moloddiu" (On social work with families, children and youth)

15. Zakon Ukrainy "Pro sotsialni posluhy" (On social services).

https://zakon.rada.gov.ua/laws/show/2671-19\#Text. Accessed 10 Nov. 2020

16. Mizhnarodni prohramy ta proekty sotsialnoi adaptatsii viiskovosluzhbovtsiv (International programs and projects of social adaptation of servicemen).

https:/www.mil.gov.ua/diyalnist/soczialnij-zaxistta-adaptacziyavijskovosluzhbovcziv/mizhnarodniprogrami-ta-proektisoczialnoi-adaptacziivijskovosluzhbovcziv.html Accessed 12 Nov. 2020

17. $\mathrm{Yu}$. L. Brindikov, Dissertation, University of Khmelnyckyi, 2018. http://tnpu.edu.ua/naukovarobota/docamentsdownload/d-58-053-

3/Dis_Bryndikov.pdf. Accessed 22 Nov. 2020

18. N. S. Oleksiuk, Dissertation, University of Lughansk. http://www.library.univer.kharkov.ua/OpacUnicode/ index.php?url=/notices/index/IdNotice:730125/Sour ce:default, 2012. Accessed 22 Nov. 2020

19. Komandor Natsionalnoi hvardii Ukrainy Dyrektyva pro vdoskonalennia orhanizatsii roboty $\mathrm{z}$ osobovym skladom Natsionalnoi hvardii Ukrainy (Commander of the National Guard of Ukraine Directive on improving the organization of work with personnel in the National Guard of Ukraine) (2017)

20. Katehorii "Viiskovo-sotsialna robota" (Categories "Military and social work"), http://www.xnb1alf1j.pp.ua/\%D0\%92\%D1\%96\%D0\%B9\%D1/

Accessed 15 Nov. 2020

21. I. A. Lypskii, Viiskovo-sotsialna robota na rivni liudyny (Military and social work at the human level). Armiia i suspilstvo 1, 84-95 (1998)

22. M. V. Kravchenko, Osnovni problemy sotsialnoho zakhystu uchasnykiv ATO (The main problems of social protection of anti-terrorist operation participants). Aspekty derzhavnoho upravlinnia 11/12 (2015)

23. M. V. Rudenko, L. V. Oliinyk, V. I. Osiodlo, V.Ž. Bogaichuk, Sotsialna viiskova pedahohika (Social military pedagogy) (NUDU, Kyiv, 2013)

24. Sotsialni problemy viiskovosluzhbovtsiv - vidpovidi na naiposhyrenishi zapytannia (Social problems of servicemen - answers to the most common questions). https://life-afterato.com.ua/post/264 Accessed 15 Nov. 2020

25. Pravovi ta sotsialni problemy viiskovosluzhbovtsiv i vymushenykh pereselentsiv (Legal and social problems of servicemen and internally displaced persons).

https://www.irf.ua/pravovi_problemy_vijskovyh/ Accessed 15 Nov. 2020

26. L. V. Tsiukalo, Sotsialne zabezpechennia viiskovosluzhbovtsiv zbroinykh syl Ukrainy ta yoho sut(Social protection of servicemen of the Armed Forces of Ukraine and its essence). Efektyvna ekonomika.

http://www.economy.nayka.com.ua/?op=1\&z=5696 Accessed 25 Nov. 2020

27. L. K. Semiv, V. R. Klos, Sotsialnyi zakhystviiskovosluzhbovtsiv: problemni pytannia $\mathrm{V}$ sotsiolohichnii otsintsi (Social protection of servicemen: problematic issues in sociological assessment) (2018)

28. Goal 10: Reduce internal inequality countries and between them, https://www.un.org/sustainable development//inequality/ Accessed 13 Nov. 2020

29. J.F. Handler, British Lessons for American Social Services, https:/www.elsevier.com/books/thecoercive-socialworker/handler/978-0-12-322850-5 Accessed 23 Nov. 2020

30. P.R. Day, Communication in social work (Elsevier)

31. K. Heap, Group Theory for Social Workers (Pergamon, 1977)

32. I. M. Trubavina, Sotsialno-pedahohichna robota $z$ simieiu: teoriia ta metodyka (Socio-pedagogical work with the family: theory and methodology) (New word, Kharkiv, 2007) 
33. C. Castro, S. Dursun (eds.), Military Veteran Reintegration (Approach, Management, and Assessment to Military Veterans Transitioning to Civilian Life) (Academic Press, 2019)

34. W. Williams, R.F. Elmore, Social Program Implementation (1976)

35. V. Odintsov, US Department of Veterans Affairs. Foreign military review. http://pentagonus.ru/publ/ministerstvo_po_delam_v eteranov ssha 2016/19-1-0-2704 (2016). Accessed 28 Nov. 2020

36. I. Yu. Marko, E. I. Marko, I. M. Chernyshova, Zarubizhnyi dosvid zabezpechennia sotsialnykh harantii viiskovosluzhbovtsiv (Foreign experience in providing social guarantees for servicemen). Zbirnyk naukovykh prats Tsentru voienno-stratehichnykh doslidzhen Natsionalnoho universytetu oborony Ukrainy imeni Ivana Cherniakhovskoho 2 (66), 135142 (2019)

37. Sozialdienst der

Armee, https://www.vtg.admin.ch/de/meinmilitaerdienst/dienstleistende/sozialdienst.html Accessed 29 Nov. 2020

38. Miliz-Sozial ber aterbeim Sozial dienst der Armee. https://www.vtg.admin.ch/de/karriere/milizkarriere/s ozialberater.html Accessed 29 Nov. 2020

39. D. R. Diamond, J. B. McLoughlin, B. H. Massam, The Service Hub Concept in Human Services Planning

40. Zakon Ukrainy "Pro sotsialnyi i pravovyi zakhyst viiskovosluzhbovtsiv ta chleniv yikh simei" (On social and legal protection of servicemen and members of their families). http://zakon0.rada.gov.ua/laws/show/2011-12 (1991). Accessed 10 Nov. 2020

41. V. I. Savytskyi, Osoblyvosti viiskovoi sotsialnoi roboty z riznymy katehoriiamy kliientiv (Features of military social work with different categories of clients).

https://ela.kpi.ua/bitstream/123456789/4875/1/11\%2 0-\%201 9 \%20-\%2022.pdf Accessed 28 Nov. 2020

42. E. V. Kovruzhkyna, Military and social work at the stage of construction and reform of the Russian Armed Forces: Socio-philosophical analysis), Dissertation

43. A. O. Kobzar, O. V. Kopanytsya, V. M. Hrytsyuk, Vykhovna robota u Zbroinykh Sylakh Ukrainy (Educational work in the Armed Forces of Ukraine) (National University of Defense of Ukraine, Kyiv, 2010)

44. O. Bazaluk, Teoriia viiny ta myru. Filosofskyi aspekt (Theory of war and peace. Philosophical aspect). https://www.researchgate.net/

publication/329979069_The_philosophy_of_War_a nd_Peace (2016). Accessed 28 Nov. 2020
45. Filosofsko-metodolohichni problemy viiskovoi teorii ta praktyky (Philosophical and methodological problems of military theory and practice). (NUDU, Kyiv, 2017)

46. Filosofiia. Filosofsko-metodolohichni problemy voiennoi teorii ta praktyky (Philosophy. Philosophical and methodological problems of military theory and practice). (NADU, Kyiv, 2000)

47. V. A. Ananin, Filosofsko-sotsiolohichni problemy myru, viiny ta armii (Philosophical and sociological problems of peace, war and the army) (KMICM, Kyiv, 1996)

48. M. Tsiurupa, Viiskovi teoretyky Yevropy pro viinu, sviti ta natsionalnoi bezpeky (porivnialnyi analiz kontseptsii viiskovo-teoretychnykh shkil Yevropy druhoi polovyny XIX - pochatku XX stolittia (European military theorists on war, peace and national security (a comparative analysis of the concepts of military-theoretical schools in Europe in the second half of the XIX - early XX century) (Kugets, Kyiv, 2005)

49. E. Toffler, War and anti-war (What is war and how to fight it. How to survive at the dawn of the XXI century) (AST, Transit Book, Moscow, 2005)

50. ACT NATO. Multiple Future Project: Navigating Towards 2030. https://sodas.ku.dk/projects/covid19projects/the-dynamics-of-politicaldiscourse-andattention-during-the-covid-19-

outbreak/?pure $=$ en $\% 2$ Fpublications $\% 2$ Fmultiplefuturesproject-navigating-towards-2030(73041bbe6104-48b3-8353-d86ccale64c1).html Accessed 30 Nov. 2020

(2009).

51. Suchasna hibrydna viina: novi formy ahresii (Modern hybrid war: new forms of aggression). http://ua.racurs.ua/1063-suchasna-gibrydna-viynata-yiyividobrajennya-u-virtualniy-realnostichastyna-2 (2016). Accessed 30 Nov. 2020

52. Svitova hibrydna viina: ukrainskyi front (World Hybrid War: Ukrainian Front) (NISS, Kyiv, 2017)

53. O. O. Illiuk, Liudskyi faktor viiskovykh formuvan (zmist, otsiniuvannia ta prohnozuvannia) (Human factor of military formations (content, evaluation and forecasting)) (AIT of MIA, Kharkov, 2012)

54. T. L. Bilous, Formuvannia osoblyvostei samorehuliatsii psykhichnykh staniv pratsivnykiv orhaniv vnutrishnikh sprav Ukrainy v ekstremalnykh umovakh (Development of features of selfregulation of mental states of employees of law enforcement units of Ukraine in extreme conditions), in International Scientific-Practical Conference Theoretical and applied researches in the field of pedagogy, psychology and social sciences, December 28-29, 194-198 (2016)

55. Sotsialna vzaiemodiia $\mathrm{v}$ systemi sotsialnoi roboty (Social interaction in the system of social work). http://www.fsn.unn.ru/wp-content/uploa ds/sites/5/Sotsialnoe-vzaimodejstvie-a-sisteme- 
SR.pdf (Nizhny Novgorod State University Publishing House, Nizhny Novgorod, 2011). Accessed 29 Nov. 2020

56. Aktualni problemy sotsialnoi roboty $\mathrm{z}$ zhinkamy (Current issues of social work with women) (tutorial for students of specifications 231 "Social work" and 232 Social protection, Field of knowledge 23 "Social work").

http://dspace.udpu.edu.ua/bitstream/6789/8961/1/\% d0\%90\%d0\%ba\%d1\%82\%d1\%83\%d0\%b0\%d0\%bb $\% \mathrm{~d} 1 \% 8 \mathrm{c} \% \mathrm{~d} 0 \% \mathrm{bd} \% \mathrm{~d} 1 \% 96 \% 20 \% \mathrm{~d} 0 \% \mathrm{bf} \% \mathrm{~d} 1 \% 80 \%$ d0\%be \%d0\%b1\%d0\%bb\%d0\%b5\%d0\%bc\%d0\%b8 $\% 20 \%$ d1 $\% 81 \%$ d0\%be\%d1\%86.\%20\%d1\%80\%d0 $\%$ be $\%$ d0\%b1.\%20\%d0\%b7\%20\%d0\%b6\%d1\%96 $\% \mathrm{~d} 0 \% \mathrm{bd} \% \mathrm{~d} 0 \% \mathrm{ba} \% \mathrm{~d} 0 \% \mathrm{~b} 0 \% \mathrm{~d} 0 \% \mathrm{bc} \% \mathrm{~d} 0 \% \mathrm{~b} 8$.pdf (Vizavi, Uman, 2018). Accessed 29 Nov. 2020

57. N. Ye. Gusak, O. P. Neskordiana, Viiskovi sotsialni pratsivnyky V Spoluchenykh shtatakh Ameryky (Military social employees in the United States). Naukovi zapysky NaUKMA 188, 61-65 (2016)

58. Yu. Ya. Taran, Sotsialna adaptatsiia kolyshnikh viiskovosluzhbovtsiv ta chleniv yikh simei (Social adaptation of ex-servicemen and members of their families). Work and social relations 1, 149-156 (2007)

59. Goal 16, Promote a peaceful and open society for sustainable development, ensure access to justice for all and establish effective, accountable and participatory institutions at all levels). https://www.un.org/sustainabledevelopment/ru/peac e-justice/ Accessed 2 Dec, 2020

60. Osvitnia prohrama "Sotsialna robota" (Educational program "Social work") https://www.ukma.edu.ua/ects/index.php/fsnst/1872018-06-13-09-07-15/c/260-2018-11-01-10-30-04

(National University of Kyiv-Mohyla Academy, 2020). Accessed 1 Dec. 2020

61. Curriculum of the advanced training program "Social work with servicemen and military-social work in the context of sustainable development of society" http://npu.edu.ua/faculty/cpo/docs/navchalnyj_plan _pidvyshchennja_kvalifikatsiji_vchyteliv_social_wo rk.pdf (Volodymyr Hnatiuk Ternopol National Pedagogical University, 2020). Accessed 15 Dec. 2020

62. International Scientific-Practical Conference "Actual Problems of Psychology, Sociology, Social Work and Professional Training of Specialists" https://www.eeda.sk/dok/konferencie/2018/10/Aktu alneproblemy-soc-vedy-2018-Pozvanka.pdf (Europska VEDA, 2018). Accessed 3 Dec, 2020

63. Z. Saralieva, Spetsyfika profesiinoi diialnosti sotsialnykh pratsivnykiv (Specifics of professional activity of social employees) (NISOC Publishing House, Nizhny Novgorod, 2015) 